ORIGINAL ARTICLE

\title{
Biological monitoring of kidney function among workers occupationally exposed to trichloroethylene
}

\author{
T Green, J Dow, C N Ong, V Ng, H Y Ong, Z X Zhuang, X F Yang, L Bloemen
}

Occup Environ Med 2004;61:312-317. doi: 10.1136/oem.2003.007153

See end of article for authors' affiliations

Correspondence to: Dr T Green, Syngenta Central Toxicology Laboratory, Alderley Park, Macclesfield, Cheshire SK10 4TJ, UK; trevor. green@syngenta.com

Accepted 30 May 2003

\begin{abstract}
Aims: To investigate the nephrotoxic potential of trichloroethylene in a currently exposed population using sensitive urinary markers of kidney toxicity.

Methods: Renal dysfunction was monitored in a cross-sectional study of 70 workers currently exposed to trichloroethylene. An age and sex matched control population of 54 individuals was drawn from hospital and administrative staff.

Results: The mean exposure to trichloroethylene, estimated from urinary trichloroacetic acid concentrations, was $32 \mathrm{ppm}$ (range $0.5-252 \mathrm{ppm}$ ) with an average duration of exposure of 4.1 years (range 1-20 years). Significant differences between the exposed and control populations were found for nephrotoxicity markers N-acetylglucosaminidase (NAG) and albumin, and for the mode of action marker, formic acid. However, neither NAG nor albumin showed a significant correlation with either the magnitude or duration of exposure to trichloroethylene. There was a significant correlation between urinary formic acid and trichloroacetic acid concentrations. Within the exposed population there were dose dependent increases in urinary methylmalonic acid concentrations and urinary glutathione S-transferase $\alpha$ activity. Although still within the control range, these changes were clearly dose dependent and consistent with one of the proposed mechanisms of trichloroethylene induced kidney toxicity.

Conclusion: Although there was no evidence of kidney toxicity within the population studied, the results suggest that kidney damage could occur at exposure concentrations higher ( $>250 \mathrm{ppm})$ than those encountered in this study.
\end{abstract}

$\mathrm{T}$ richloroethylene was first manufactured in quantity in the 1920s and has had a wide variety of uses since that time which include food processing, as a solvent in domestic products, and as a general anaesthetic. Its main use has always been for vapour degreasing of metals and today $90 \%$ of trichloroethylene is used in this way. ${ }^{1}$ The most heavily exposed populations have always been those engaged in metal cleaning processes, exposure occurring through inhalation of trichloroethylene vapour, and to a lesser extent through skin contamination with the liquid. Health effects, normally associated with high acute exposures, have been well characterised and are primarily associated with changes in the CNS and liver. ${ }^{1}$

The health risks associated with chronic exposure to trichloroethylene have been addressed by several epidemiology studies looking at the large cohorts exposed to this chemical since it was first used extensively in industry. To date these studies have failed to establish a clear link between chronic exposure to trichloroethylene and an increase in cancer rates in the exposed populations. By contrast, cancer studies in animals have found increases in liver and lung tumours in mice and a low incidence of renal cancer in rats exposed to toxic dose levels. ${ }^{1}$ Of the animal tumours, mechanistic studies suggest that only the rat kidney tumours may be indicative of a human health hazard. ${ }^{2}$

Contrary to the findings of the large epidemiology studies, Henschler and colleagues ${ }^{3}$ and Vamvakas and colleagues ${ }^{4}$ reported significant increases in renal cancer in two small populations exposed in factories in Germany. There were no direct measures of exposure, this being assessed retrospectively, either from the exposed individuals, or from relatives, 20-25 years after exposure had ceased. The apparent discrepancy between the outcome of these studies and the large cohort studies is attributed, by the authors, to the uniquely high exposures that occurred in Germany at that time.

As in the rat studies, kidney toxicity is believed to be a prerequisite for the development of renal cancer in humans following exposure to trichloroethylene. ${ }^{5}$ In support of the belief that exposures were extremely high in the German studies, a number of reports identifying kidney damage within the exposed populations have been published..$^{5-10}$ As with the cancer studies direct evidence of exposure is lacking. Furthermore, these studies measured a number of sensitive urinary markers of kidney dysfunction, including several microglobulins, retinol binding protein, and glutathione Stransferase $\alpha$, which vary widely within the normal human population and are affected by age and sex, by a wide range of lifestyle factors including smoking and exercise, and by a wide variety of disease states and drug therapies. ${ }^{11}{ }^{12}$ Since the populations studied were small, typically 10-20 individuals, the possibility of a correlation between kidney toxicity and exposure occurring by chance is high, particularly in the absence of a direct exposure assessment.

Kidney toxicity has therefore become the critical parameter in the evaluation of the carcinogenic risk to humans following chronic exposure to trichloroethylene. Mechanistic studies in rodents and to a lesser extent in humans have identified metabolic pathways which may lead to renal toxicity, particularly at high dose levels. One, a very minor pathway involving glutathione conjugation of trichloroethylene, which leads to the formation of isomers S-(dichlorovinyl) cysteine (DCVC), a known renal toxicant, has been

Abbreviations: $\alpha 1 M, \alpha-1$-microglobulin; ALB, albumin; $\beta 2 M$ $\beta$-2-microgobulin; DCVC, S-(dichlorovinyl) cysteine; GST- $\alpha$, glutathione S-transferase $\alpha$; MMA, methylmalonic acid; NAG, Nacetylglucosaminidase; NAGA, heat labile NAG; NAGB, heat stable NAG; RBP, retinal binding protein; TCA, trichloroacetic acid; $U$, urinary 
Main messages

- There was no evidence of kidney damage in populations exposed to $250 \mathrm{ppm}$, or lower concentrations, of trichloroethylene.

- Dose dependent increases in urinary formate, methylmalonate, and glutathione transferase $\alpha$ suggest that trichloroethylene interferes with folate metabolism, causing an acidosis which could result in kidney damage at high $(<250 \mathrm{ppm})$ exposure concentrations.

identified in rats and humans. ${ }^{2}$ An alternative mechanism, based on trichloroethylene induced vitamin $\mathrm{B}_{12}$ deficiency in the rat and the excretion of large amounts of formic acid, has also been proposed..$^{13} 14$

The opportunities to study populations currently exposed to trichloroethylene where both direct measurements of exposure can be made and renal toxicity can be assessed using the same sensitive markers that were used in the previous studies, is rare. In this paper we present the results of a study in which renal toxicity has been assessed in a population whose exposure to trichloroethylene has been determined by environmental exposure measurements and by urinary trichloroacetic acid concentrations. It also seemed prudent to determine whether any increase in toxicity was accompanied by evidence that one of the proposed mechanisms was operative, thus both lending weight to the observation of toxicity and also helping to resolve which of the proposed mechanisms was responsible. To that end urinary concentrations of $\mathrm{N}$-acetyl DCVC, as an indicator of DCVC formation, and formic acid and methylmalonic acid, the latter a marker of vitamin $\mathrm{B}_{12}$ deficiency, have also been determined.

\section{METHODS}

\section{Study subjects}

A cross-sectional study was carried out on 70 workers (58 males, 12 females) in electronic and related industries from several factories. Trichloroethylene was the only organic solvent that these workers were exposed to. This chemical was used as a degreaser for cleaning the surface of metal parts. The workers were all healthy, with no medical history of renal or urinary tract diseases. Another 54 (50 males, 4 females) age matched hospital and administrative staff with no known history of exposure to organic solvents or heavy metals were recruited as controls.

All of the subjects fulfilled the following criteria: no past or family history of renal disease, hypertension, or diabetes mellitus; no evidence of haematuria on Clinistix examination; systolic blood pressure of less than $140 \mathrm{~mm} \mathrm{Hg}$ and diastolic blood pressure below $90 \mathrm{~mm} \mathrm{Hg}$; non-smoker; not pregnant if female; and not on any medication such as antibiotics or analgesics for the two weeks prior to examination. The mean ages of the exposed and non-exposed workers were comparable, 32.6 (9.2) years and 30.3 (9.1) years, respectively.

\section{Urinary analyses}

Spot urine samples were collected from subjects at midday after four days of exposure and immediately placed at $4^{\circ} \mathrm{C}$. They were subsequently stored at $-30^{\circ} \mathrm{C}$. Analyses for various parameters were carried out within two months.

The activities of urinary $\mathrm{N}$-acetyl glucosaminidase (NAG) and glutathione $S$-transferase $\alpha$ were determined prior to freezing using commercially available diagnostic kits (Boehringer Mannheim Biochemica; Biotrin NEPHKIT- $\alpha$,
Policy implications

- No evidence of kidney damage under current occupational exposure conditions.

- Kidney damage could occur if these exposure levels are exceeded.

respectively). ELISA methods were used to determine the urinary microproteins: retinol binding protein (RBP), $\beta 2 \mathrm{M}$, and $\alpha \mathrm{lM}$ concentrations. Total protein was measured using Bio-Rad Dc Protein assay kit. All the biological parameters were standardised for variability in urinary flow using urinary creatinine concentration and expressed as per gram creatinine.

$\alpha-1$ Microglobulin was determined using a competitive ELISA. The ELISA plates (96 wells) were first coated with $12 \mu \mathrm{g} / \mathrm{ml}$ of rabbit antihuman $\alpha-1$ microglobulin in carbonate buffer ( $\mathrm{pH}$ 9.6) overnight at $4{ }^{\circ} \mathrm{C}$ and subsequently washed three times with phosphate buffered saline buffer (PBS; $20 \mathrm{mM}$ sodium phosphate, $150 \mathrm{mM}$ sodium chloride, $\mathrm{pH} 8.0$, containing $0.1 \%$ BSA $+0.1 \%$ Tween 20). The standards were prepared by diluting $440 \mathrm{mg} / \mathrm{l}$ of $\alpha-1$ microglobulin to a concentration of $4.4 \mathrm{mg} / \mathrm{l}$. This solution was further diluted by performing a two times serial dilution for nine times (that is, a total of 10 standards for the calibration curve). The urine samples were diluted $1 / 50$ in incubation buffer (PBS with $0.1 \%$ BSA). Standard and diluted urine samples ( $100 \mu \mathrm{l})$ were added into the respective wells. Biotinylated $\alpha-1$ microglobulin $(100 \mu \mathrm{l})$ was then added to all wells. After incubation at $4^{\circ} \mathrm{C}$ overnight the plate was washed with washing buffer and $200 \mu \mathrm{l}$ of avidinalkaline phosphatase (1/10 000 dilution) was added into all wells. The plate was then incubated for two hours at $37^{\circ} \mathrm{C}$; followed by three washes. After that, the wells were filled with $200 \mu \mathrm{l}$ of substrate $(1 \mathrm{mg} / \mathrm{ml}$ of p-nitrophenyl phosphate in $1 \mathrm{M}$ diethanolamine buffer, $\mathrm{pH} 9.8$ ) and further incubated at room temperature for 20-30 minutes. The absorbance was then read at $405 \mathrm{~nm}$ with a microplate reader and $\alpha-1$ microglobulin concentrations were calculated using the Bio-Rad Laboratories Microplate Manager software.

$\beta-2$ Microglobulin was determined as follows. An affinity purified rabbit antihuman $\beta-2$ microglobulin $(10 \mu \mathrm{g} / \mathrm{ml})$ was used as a capture antibody and adsorbed onto a 96 well plate in carbonate buffer, pH 9.6. After overnight incubation at $4{ }^{\circ} \mathrm{C}$, the plate was washed three times with washing buffer with PBS containing $0.25 \%$ gelatin. Standard $\beta-2$ microglobulin and diluted urine samples $(200 \mu \mathrm{l})$ were then added into their respective wells. The standards were prepared by serial diluting $84 \mathrm{ug} / \mathrm{l}$ of $\beta-2$ microglobulin standard nine times (that is, a total of 10 standards for the calibration curve). The urine samples were diluted $1 / 10$ with the same PBS buffer. The plates were incubated overnight at $4^{\circ} \mathrm{C}$. After washing the plates for three times, $200 \mu \mathrm{l}$ of anti- $\beta-2$ microglobulin conjugated with horseradish peroxidase and diluted with incubation buffer as specified by the manufacturer, was added into each well. The plates were then incubated for one hour at $37^{\circ} \mathrm{C}$, followed by three washes. The substrate solution consisting of $4 \mathrm{mg} / 100 \mathrm{ml}$ of o-phenylenediamine (OPD) in $0.1 \mathrm{M}$ citrate buffer, $\mathrm{pH} 5.0$ was freshly prepared; $2 \mu \mathrm{l}$ of $30 \%$ hydrogen peroxide was added to each $\mathrm{ml}$ of OPD solution prepared. Substrate $(200 \mu \mathrm{l})$ was added into each well. The enzymatic reaction was stopped after 15 minutes' incubation in the dark with $50 \mu \mathrm{l}$ of $5 \mathrm{M} \mathrm{H}_{2} \mathrm{SO}_{4}$. The absorbance was read at $490 \mathrm{~nm}$ with a microplate reader, and $\beta-2$ microglobulin concentrations 
were calculated using the Bio-Rad Laboratories Microplate Manager software.

Retinol binding protein (RBP) was determined in a similar manner. In this case the 96 wells plates were coated with $10 \mu \mathrm{g} / \mathrm{ml}$ of rabbit anti human retinol binding protein in carbonate buffer $\mathrm{pH} 9.6$, overnight at $4^{\circ} \mathrm{C}$. A volume of $200 \mu \mathrm{l}$ of standard RBP or diluted urine was added into their respective wells of the precoated and washed 96 well plate (described above). The standards were prepared by serial diluting $335 \mu \mathrm{g} / \mathrm{l}$ of RBP standard nine times (that is, a total of 10 standards for the calibration curve). The urine samples were diluted $1 / 20$ in incubation buffer (PBS with $0.1 \%$ BSA). After overnight incubation at $4{ }^{\circ} \mathrm{C}$ the plates were washed three times. A $200 \mu \mathrm{l}$ aliquot of anti-RBP conjugated with horseradish peroxidase (1/500 dilution factor) was added to each well and the plates incubated for one hour at $37^{\circ} \mathrm{C}$. After washing three times, $200 \mu \mathrm{l}$ of the substrate was added into each well. The substrate was freshly prepared by adding $40 \mathrm{mg} / 100 \mathrm{ml}$ of o-phenylenediamine (OPD) in citrate buffer, and $2 \mu \mathrm{l}$ of $30 \% \mathrm{H}_{2} \mathrm{O}_{2}$ was added to each ml of ODP solution. Thereafter, the plates were further incubated at room temperature in the dark for exactly 15 minutes. The reaction was stopped by adding $50 \mu \mathrm{l}$ of $10 \mathrm{~N} \mathrm{H}_{2} \mathrm{SO}_{4}$ into each well. The absorbance was read at $490 \mathrm{~nm}$ using a microplate reader, and RBP concentrations were calculated using the Bio-Rad Laboratories Microplate Manager software.

Total $\mathrm{N}$-acetyl- $\beta$-D-glucosaminidase (NAG) was determined as follows. A set of standards with concentrations of $0.0 \mathrm{U} / \mathrm{l}, 9.08 \mathrm{U} / \mathrm{l}, 18.16 \mathrm{U} / \mathrm{l}$, and $27.24 \mathrm{U} / \mathrm{l}$ were prepared from a stock solution of $27.24 \mathrm{U} / \mathrm{l}$. A commercially prepared sample of $9.53 \mathrm{U} / \mathrm{l}$ was used as a control (Roche Diagnostics, Switzerland). A $500 \mu \mathrm{l}$ aliquot of substrate solution containing sodium 3 -cresolsulphonphthaleinyl- $N$-acetyl- $\beta$-D-glucosaminidase was pipetted into $5 \mathrm{ml}$ test tubes and incubated at $37^{\circ} \mathrm{C}$ for five minutes. A $25 \mu \mathrm{l}$ urine sample was then added to the substrate solution and mixed well. At exactly 15 minutes, $1.0 \mathrm{ml}$ of sodium carbonate was added into the mixture and vortexed to stop the reaction. Thereafter, the tube was allowed to stand at room temperature for 10 minutes before the measurement was taken against the blank at a wavelength of $580 \mathrm{~nm}$.

There are two main NAG isoenzymes which differ in their heat sensitivity in human kidney. Isoenzyme $\mathrm{A}$ is heat labile whereas isoenzyme $\mathrm{B}$ is heat stable. The separation of the heat stable NAG-B and heat-labile NAG-A isoenzymes can be carried out by heating the urine sample for 30 minutes at $55^{\circ} \mathrm{C}$. The amount of heat labile NAGA was calculated by subtracting heat stable NAGB from the total NAG. ${ }^{15}$

Urinary glutathione S-transferase $\alpha$ was determined using a Biotrin NEPHKIT human GST- $\alpha$ assay. Urine samples were diluted with an equal volume of sample diluent. Diluted samples, calibrators, and positive control $(100 \mu \mathrm{l})$ were added into the respective wells. The microassay plates were incubated at room temperature $\left(20-25^{\circ} \mathrm{C}\right)$ for 60 (2) minutes with uniform shaking. After four washes, $100 \mu \mathrm{l}$ of conjugate (anti- $\alpha \mathrm{GST}$ IgG conjugated to horseradish peroxidase containing thiomersal) was added into each well and the incubation continued at room temperature for 30 (2) minutes with uniform shaking. Again, the plates were washed four times. A volume of $100 \mu \mathrm{l}$ TMB substrate was added into each well and incubated at room temperature for another 15 minutes. The reaction was stopped by adding $100 \mu \mathrm{l} \mathrm{l} \mathrm{N}$ sulphuric acid into each well. The absorbance was read at $450 \mathrm{~nm}$ using a microplate reader, and glutathione $S$-transferase $\alpha$ concentration was calculated using Bio-Rad Laboratories Microplate Manager software.

\section{Metabolite analysis}

Trichloroethanol and its glucuronide were determined by NMR. Urine samples $(500 \mu \mathrm{l})$ were treated with phosphate buffer $\left(250 \mu \mathrm{l}\right.$ of $0.2 \mathrm{M} \mathrm{Na}_{2} \mathrm{HPO}_{4} / 0.2 \mathrm{M} \mathrm{NaH} \mathrm{PO}_{4}, \mathrm{pH} 7.4$; prepared in $\mathrm{D}_{2} \mathrm{O}$ ) containing sodium-3-(trimethylsilyl)-propionate-2,2,3,3- $\mathrm{d}_{4}$ (TSP; $0.5 \mathrm{mg} / \mathrm{ml}$ buffer) as an internal standard. The samples were centrifuged at $14000 \mathrm{~g}$ for 10 minutes at $4^{\circ} \mathrm{C}$ and the supernatant $(600 \mu \mathrm{l})$ was transferred to a $5 \mathrm{~mm}$ NMR tube. $1 \mathrm{H}$ NMR spectra were acquired using a Bruker DPX400 spectrometer operating at 400.13 MHz for proton spectroscopy. Water suppression was achieved by employing the standard "noesyprld" Bruker pulse sequence for data acquisition. All spectra were phase and baseline corrected before the signals were integrated. The concentration of trichlorothethanol glucuronide was obtained using the integral of the signal for the protons of the methylene group $\left(\mathrm{CCl}_{3} \mathbf{C H}_{2}\right.$-O-glucuronide, $\mathrm{AB}$ pattern at $4.42 \mathrm{ppm})$ and relating this to the signal for the internal standard $\left(\left(\mathbf{C H}_{3}\right)_{3} \mathrm{SiCD}_{2} \mathrm{CD}_{2} \mathrm{COO}^{-} \mathrm{Na}^{+}\right.$, singlet at $\left.0 \mathrm{ppm}\right)$. The limit of quantitation was $27 \mu \mathrm{g} / \mathrm{ml}$.

Trichloroacetic acid was determined as its N-methyl $\mathrm{N}$-(tertbutyldimethylsilyl) trifluoroacetamide (MTBSTFA) derivative by gas chromatography-mass spectrometry. Urine samples were adjusted to $\mathrm{pH} l$ by the addition of $50 \mu \mathrm{l}$ of $5 \mathrm{~N}$ hydrochloric acid and extracted with $2 \times 2 \mathrm{ml}$ of diethyl ether. The extracts were combined and a $200 \mu \mathrm{l}$ aliquot derivatised with $100 \mu \mathrm{l}$ MTBSTFA at $100^{\circ} \mathrm{C}$ for at least 40 minutes. After allowing the vials to cool, the contents were transferred to microvolume inserts and $2 \mu \mathrm{l}$ was injected by an autosampler onto the GC-MS (HewlettPackard MSD). A $0.25 \mathrm{~mm} \times 30 \mathrm{~m}$ RTXI capillary column was used for the analysis. The initial column temperature was $100^{\circ} \mathrm{C}$ for 3 minutes followed by a linear gradient to $190^{\circ} \mathrm{C}$ over 10 minutes. Under these conditions the tertbutyldimethylsilyl derivative of trichloroacetic acid had a retention time of 6.9 minutes. The following ions were monitored by the mass spectrometer: trichloroacetic acidTBDMS, 190.8, 192.8, 218.8, 220.8 (M-57+1). Trichloroacetic acid was quantified against a standard curve prepared by adding known amounts to urine $(0-400 \mu \mathrm{g} / \mathrm{ml})$ and analysing as above. The limit of quantitation was $1 \mu \mathrm{g} / \mathrm{ml}$ urine.

\section{Mode of action markers}

Formic acid and methylmalonic acid (markers of folate and vitamin $B_{12}$ deficiency respectively) were determined as described previously. ${ }^{14}$ The limits of quantitation of the assays were $1 \mu \mathrm{g} / \mathrm{ml}$ and $0.2 \mu \mathrm{g} / \mathrm{ml}$ respectively. Urine samples from the 10 highest exposed individuals were also analysed for $\mathrm{N}$-acetyl-S-(1,2-dichlorovinyl)-L-cysteine (N-acetyl DCVC) using the method described by Bernauer and colleagues, ${ }^{16}$ with the exception that the mass spectrometer was used in the electron impact mode rather than chemical ionisation. The limit of quantitation of the assay was $5 \mathrm{ng} / \mathrm{ml}$.

\section{Statistical analysis}

Statistical analysis was conducted using the SAS statistical programs ${ }^{17}$ To obtain maximum statistical power, categorical analysis was used in the analysis of duration, level of exposure, and effect. To that end, the exposure group was divided into four subgroups containing, where possible, equal numbers of subjects. However, because several subjects had the same values for some tests, equal categories were not always possible. Categorical analysis was preferred over the continuous model because the latter assumes exposure is exponentially related to response, whereas the former allows for assessment of what dose-response relation does exist, if any, without any assumption about the form of the curve. The $\chi^{2}$ test showed no difference in gender for the various 
biomarkers in both groups and data from males and females were therefore combined.

\section{RESULTS}

\section{Exposure}

The median duration of exposure for the exposed workers was $4.1 \pm 4.5$ years, ranging from less than 1 year to 20 years. There was evidence of exposure, based on the presence of trichloroacetic acid in urine, in all 70 of the exposed group. The mean concentration of trichloroacetic acid was $72 \pm 84$ $\mathrm{mg} / \mathrm{g}$ creatinine (range 1-386). Urinary trichloroacetic acid levels have been shown to correlate well with exposure, a concentration of $100 \mathrm{mg} / \mathrm{l}$ equating to a TRI exposure of $50 \mathrm{ppm}$ over several shifts. ${ }^{18}$ It was assumed that this relation held over the range of concentrations measured in this study. In this study the mean concentration of trichloroacetic acid expressed in mg/l was $64 \pm 102$ (range l-505), equating to a mean trichloroethylene exposure concentration of $32 \mathrm{ppm}$ (range 0.5-252 ppm). Within this range two individuals were exposed to around $250 \mathrm{ppm}$, five were exposed to more than $100 \mathrm{ppm}$, three were exposed to between 100 and $50 \mathrm{ppm}$, and the remainder $(n=60)$ were exposed to less than $50 \mathrm{ppm}$. The mean trichloroethanol concentration in these samples was $122 \pm 119 \mathrm{mg} / \mathrm{g}$ creatinine (range 1-639). Although both trichloroacetic acid and trichloroethanol could be detected in the exposed samples, the ratio of the two metabolites varied considerably between individuals (mean ratio TCE:TCA $=3.1 \pm 3.4$, range $0.6-20.1$ ).

\section{Renal toxicity markers}

All values for both toxicity markers and for biomarkers of exposure were normalised by expressing the data per gram of urinary creatinine. A comparison (mean (SD)) of the markers of renal toxicity between control and exposed populations gave significant differences for the NAG enzymes (total, heat stable, and NAGA; p < 0.01), and for urinary albumin $(\mathrm{p}<0.05)$ (table 1$)$. There were no significant differences between exposed and controls in the concentrations of $\alpha-1$ and $\beta-2$ microglobulins, retinol binding protein, total protein, or glutathione S-transferase $\alpha$.

The increases in NAG enzymes and urinary albumin within the exposed population suggested impaired renal function as a result of trichloroethylene exposure. However, when these parameters were compared within the exposed group there was no correlation between either the NAG enzymes or albumin and urinary trichloroacetic acid concentrations or years of exposure to trichloroethylene. Table 2 shows the

Table 1 Comparison of renal toxicity and mechanism based markers between exposed and control groups

\begin{tabular}{|c|c|c|c|}
\hline \multirow[b]{2}{*}{ Parameter } & \multicolumn{2}{|c|}{$\begin{array}{l}\text { Activity/concentration, } \\
\text { mean (SD) }\end{array}$} & \multirow{2}{*}{$\begin{array}{l}\text { Significance } \\
\text { (p) }\end{array}$} \\
\hline & Control $(n=54)$ & Exposed $(n=70)$ & \\
\hline GST- $\alpha(\mu \mathrm{g} / \mathrm{g})$ & $6.18(5.17)$ & $8.25(9.56)$ & NS (0.15) \\
\hline Urinary RBP $(\mu \mathrm{g} / \mathrm{g})$ & $40.6(24.6)$ & $39.9(37.9)$ & NS $(0.91)$ \\
\hline Urinary ALB (mg/g) & $5.50(4.27)$ & 9.71 (11.6) & $<0.05^{\star}$ \\
\hline Urinary $\alpha 1 M(\mathrm{mg} / \mathrm{g})$ & $3.83(1.85)$ & $5.06(4.84)$ & NS (0.08) \\
\hline Urinary $\beta 2 M(\mathrm{mg} / \mathrm{g})$ & $70.4(33.9)$ & $81.9(67.6)$ & NS $(0.26)$ \\
\hline Total NAG (U/g) & 2.41 (1.91) & 5.27 (3.78) & $<0.01 \dagger$ \\
\hline NAGB (U/g) & $0.63(0.83)$ & $1.96(2.11)$ & $<0.01 \dagger$ \\
\hline NAGA (U/g) & $1.79(1.51)$ & $3.31(2.68)$ & $<0.01 \dagger$ \\
\hline Total protein $(\mathrm{mg} / \mathrm{g})$ & 19.5 (17.1) & $22.8(34.5)$ & NS (0.54) \\
\hline Formate $(\mathrm{mg} / \mathrm{g})$ & $5.55(3.00)$ & $9.45(4.78)$ & $<0.01 \dagger$ \\
\hline MMA $(\mathrm{mg} / \mathrm{g})$ & $1.91(1.23)$ & $2.00(1.30)$ & NS (0.68) \\
\hline
\end{tabular}

Parameters expressed per gram creatinine. NS, not significant.

*Statistically different at the $5 \%$ level by Student's $t$ test. †Statistically different at the $1 \%$ level by Student's $t$ test.
Table 2 Correlation of renal toxicity markers with magnitude and duration of exposure to trichloroethylene

\begin{tabular}{|c|c|c|c|c|}
\hline $\begin{array}{l}\text { Parameter I/ } \\
\text { group }\end{array}$ & $\begin{array}{l}\text { Parameter II, } \\
\text { mean }\end{array}$ & $\begin{array}{l}\text { Correlation } \\
\text { coefficient }\end{array}$ & $\mathrm{R}^{2}$ & $\begin{array}{l}\text { Significance } \\
\text { (p) }\end{array}$ \\
\hline TCA & GST- $\alpha$ & & & \\
\hline$<18$ (19) & 5.66 & & & \\
\hline $18-43(17)$ & 5.69 & & & \\
\hline $43-103$ (17) & 10.12 & & & \\
\hline $103-386$ (17) & 11.82 & 0.439 & 0.192 & $<0.01 \dagger$ \\
\hline Years* & GST- $\alpha$ & & & \\
\hline $0-1(15)$ & 8.62 & & & \\
\hline $1-4(24)$ & 8.50 & & & \\
\hline $4-7$ (17) & 6.91 & & & \\
\hline $7-20$ (13) & 7.72 & 0.177 & 0.031 & NS (0.145) \\
\hline TCA & NAG & & & \\
\hline$<18(19)$ & 6.45 & & & \\
\hline $18-43$ (17) & 4.81 & & & \\
\hline $43-103$ (17) & 4.51 & & & \\
\hline $103-386$ (17) & 5.17 & 0.088 & 0.007 & NS (0.47) \\
\hline Years* & NAG & & & \\
\hline $0-1(15)$ & 3.74 & & & \\
\hline $1-4(24)$ & 5.80 & & & \\
\hline $4-7$ (17) & 6.32 & & & \\
\hline $7-20$ (13) & 5.00 & 0.045 & 0.002 & NS (0.71) \\
\hline TCA & U ALB & & & \\
\hline$<18(19)$ & 8.62 & & & \\
\hline $18-43(17)$ & 14.19 & & & \\
\hline $43-103$ (17) & 8.16 & & & \\
\hline $103-386(17)$ & 7.99 & 0.104 & 0.011 & NS (0.39) \\
\hline RBP vs age & - & 0.361 & 0.130 & $<0.01 \dagger$ \\
\hline
\end{tabular}

toxicity biomarkers compared to increasing exposure parameters divided into quartiles. A regression analysis of all of the data in each dataset has been used to produce a correlation coefficient whose significance is also given in the table.

Although not statistically increased when compared to controls, there was a trend for urinary glutathione $S$-transferase $\alpha$ activities to increase with increasing urinary trichloroacetic acid concentrations $(\mathrm{p}<0.01)$, but not with years of exposure (table 2 ). None of the parameters including NAG and glutathione S-transferase $\alpha$ correlated with age, other than retinol binding protein which was significantly correlated with age $(p<0.01)$, but not with exposure.

\section{Mechanism based markers}

Of the urinary markers indicative of the proposed modes of action of trichloroethylene as a kidney toxicant, only formic acid concentrations were significantly increased $(\mathrm{p}<0.01)$ in the exposed population compared to the controls (table 1). Within the exposed population there were significant correlations between formic acid $(p<0.01)$ and methylmalonic acid $(\mathrm{p}<0.05)$ and urinary trichloroacetic acid concentrations (table 3). Neither parameter correlated with years of exposure. Interestingly, there was also a close correlation between formic acid and methylmalonic acid and between formic acid and glutathione S-transferase $\alpha$ (both $p<0.01)$, suggesting that these increases are mechanistically linked (table 3 )

The formation of DCVC shown by the presence of $\mathrm{N}$-acetyl DCVC in urine was quantified in urine samples from the 10 highest exposed individuals (exposure range 79-252 ppm). Within this group $\mathrm{N}$-acetyl DCVC was detected in only two samples at concentrations of $5 \mathrm{ng} / \mathrm{ml}$ and $28 \mathrm{ng} / \mathrm{ml}$. The concentrations found did not correlate directly with 


\begin{tabular}{|c|c|c|c|c|}
\hline $\begin{array}{l}\text { Parameter } \\
\text { 1/group }\end{array}$ & $\begin{array}{l}\text { Parameter } \\
\text { II, mean }\end{array}$ & $\begin{array}{l}\text { Correlation } \\
\text { coefficient }\end{array}$ & $\mathrm{R}^{2}$ & $\begin{array}{l}\text { Significance } \\
\text { (p) }\end{array}$ \\
\hline $\begin{array}{l}\text { TCA } \\
<18(19) \\
18-43(17) \\
43-103(17) \\
103-386(17)\end{array}$ & $\begin{array}{l}\text { Formate } \\
6.71 \\
7.67 \\
12.49 \\
11.27\end{array}$ & 0.401 & 0.161 & $<0.01 \ddagger$ \\
\hline $\begin{array}{l}\text { Years* }^{*} \\
0-1(15) \\
1-4(24) \\
4-7(17) \\
7-20(13)\end{array}$ & $\begin{array}{l}\text { Formate } \\
8.66 \\
10.56 \\
9.58 \\
7.39\end{array}$ & 0.126 & 0.016 & NS $(0.30)$ \\
\hline $\begin{array}{l}\text { GST- } \alpha \\
0-2(20) \\
2-5(19) \\
5-15(18) \\
15-41(13)\end{array}$ & $\begin{array}{l}\text { Formate } \\
6.12 \\
8.88 \\
10.50 \\
13.97\end{array}$ & 0.514 & 0.270 & $<0.01 \ddagger$ \\
\hline $\begin{array}{l}\text { TCA } \\
<18(19) \\
18-43(17) \\
43-103(17) \\
103-386(17)\end{array}$ & $\begin{array}{l}\text { MMA } \\
1.86 \\
1.65 \\
2.13 \\
2.38\end{array}$ & 0.265 & 0.070 & $<0.05 \dagger$ \\
\hline $\begin{array}{l}\text { Years* } \\
0-1(15) \\
1-4(24) \\
4-7(17) \\
7-20(13)\end{array}$ & $\begin{array}{l}\text { MMA } \\
1.96 \\
2.03 \\
1.79 \\
2.14\end{array}$ & 0.003 & $7.4 \times 10^{-6}$ & NS (0.98) \\
\hline $\begin{array}{l}\text { Formate } \\
0-7(19) \\
7-10(21) \\
10-14(14) \\
14-20(16)\end{array}$ & $\begin{array}{l}\text { MMA } \\
1.38 \\
1.99 \\
2.27 \\
2.73\end{array}$ & 0.406 & 0.165 & $<0.01 \ddagger$ \\
\hline $\begin{array}{l}\text { GST- } \alpha \\
0-2(20) \\
2-5(19) \\
5-15(18) \\
15-41(13)\end{array}$ & $\begin{array}{l}\text { MMA } \\
2.38 \\
1.69 \\
2.07 \\
1.79\end{array}$ & 0.122 & 0.015 & NS $(0.31)$ \\
\hline
\end{tabular}

Trichloroacetic acid (TCA) was used as a biomarker of exposure. Figures in parentheses represents number of individuals per group. ${ }^{*} n=69$. Years of exposure was not available for one individual.

exposure, these two individuals being exposed to 113 and $153 \mathrm{ppm}$ respectively. The combined concentrations of the oxidative metabolites of trichloroethylene, trichloroethanol, and trichloroacetic acid, in the same individuals were 400 and $1333 \mu \mathrm{g} / \mathrm{ml}$ respectively.

\section{DISCUSSION}

Due to the high reserve capacity of the kidney, mild or early nephropathy has few or no clinical signs. Fortunately sensitive markers of kidney damage are now available to detect early or moderate loss of renal function. When detected at an early stage nephropathy may still be reversible on treatment and abatement of the exposure sources. Such markers are also useful to ensure that occupational exposure levels to potentially toxic chemicals do not entail a risk for renal function to the exposed populations. The opportunity to assess renal impairment in a population exposed to moderately high concentrations trichloroethylene, a chemical associated with renal toxicity and even renal cancer, was relatively unique. Furthermore, a direct assessment of exposure could be made using urinary trichloroacetic acid concentrations as a biomarker of exposure. Finally, the same study could be used to monitor the presence in urine of markers which were indicative of the mechanism(s) of toxicity.
Of the biomarkers available to detect early renal dysfunction urinary glutathione S-transferase $\alpha$ activity and urinary concentrations of $\beta$-2-microglobulin, $\alpha$-1-microglobulin, and retinol binding protein are reported to be more sensitive than more conventional markers such as total protein, NAG, and glucose. Previous studies, conducted 20-25 years after exposure to trichloroethylene ended, have detected changes in urinary protein patterns, including $\alpha$-1-microglobulin excretion, and in glutathione S-transferase $\alpha$ activity. ${ }^{5}$ It was interesting therefore, that in the present study the only statistically significant differences between the control and exposed populations were increases in NAG activities and urinary albumin concentration. Although neither of these parameters were reported to be increased in the previous studies, the results did, apparently, support the view that trichloroethylene exposure caused renal dysfunction. However, the major difference between the current study and previously reported studies was the fact that this population was currently exposed, and the fact that exposure data were available.

Having exposure data (as determined from urinary trichloroacetic acid concentrations) proved to be critical in the interpretation of this study; not only did it show that the increases in NAG and albumin were not related to trichloroethylene exposure, it also enabled the exposure related changes in formic acid, methylmalonic acid, and glutathione S-transferase $\alpha$ activity to be identified. The reason for the increased NAG and albumin excretion is not clear and may be explained either by chance or possibly by exposure to some unidentified agent. It was clearly not due to either the magnitude or duration of exposure to trichloroethylene. Whether urine NAG is an indicator of nephropathy is still inconclusive. Recent findings have suggested that raising urinary NAG with proteinuria is an indication of functional changes within the kidney due to the uptake of excessive amounts of materials by the proximal tubular cells. ${ }^{19}$ It is thus a measure of altered function in the renal tubules and not an indicator of damage. ${ }^{20}$ On the other hand, the changes in formate, methylmalonate, and glutathione S-transferase $\alpha$ activity were small and within the normal range and hence cannot be considered to be evidence of renal impairment. ${ }^{20-22}$ They were, however, statistically correlated with trichloroethylene exposure, but not with duration of exposure, suggesting that these changes are related to recent exposure, the effects are not cumulative, and that they probably return to control levels when exposure ceases. The belief that these were real findings is given further credence by the correlation between formate and methylmalonate and between formate and glutathione S-transferase $\alpha$ activity. Such a finding is entirely consistent with the proposed mechanism of renal toxicity which involves vitamin $B_{12}$ and folate deficiency. ${ }^{14}$ This mechanism is based on the observation that the major metabolites of trichloroethylene, trichloroacetic acid, and trichloroethanol, cause a vitamin $B_{12}$ deficiency resulting in impairment of the two biochemical pathways in which vitamin $B_{12}$ plays a role. One, the folate pathway, leads to excretion of excess formic acid in urine, the other, the conversion of methylmalonyl CoA to succinyl CoA, leads to the excretion of excess methylmalonic acid. Of these two, formate is a far more sensitive urinary endpoint than methylmalonate. Thus, it would be expected that formate excretion would be linked to methylmalonate excretion and that formate toxicity could give rise to the increase in urinary glutathione S-transferase $\alpha$ activity. In contrast, $\mathrm{N}$-acetyl DCVC was either not detectable in urine or only present at extremely low levels, nor was there any evidence to connect the dose related changes in any of the parameters with the formation of this metabolite. 


\section{Conclusion}

The only significant difference between control and exposed populations was an increase in the urinary excretion of NAG and albumin. Neither parameter correlated with exposure or duration of exposure and hence it can be concluded that exposure to trichloroethylene up to $250 \mathrm{ppm}$ does not cause renal impairment. There was evidence within the exposed population of increases in formate, methylmalonate, and glutathione S-transferase $\alpha$ activity. Although still within the control range, these changes were clearly dose dependent and consistent with one of the proposed mechanisms of trichloroethylene induced kidney toxicity. It is possible, therefore, that kidney damage could occur at exposure concentrations higher $(>250 \mathrm{ppm})$ than those encountered in this study.

\section{ACKNOWLEDGEMENTS}

These studies were sponsored by members of the European Chlorinated Solvents Association, Brussels, Belgium and the Centre for Environmental and Occupational Health, National University of Singapore. We thank Drs WY Lam, Mandy Ho, Mr Tsin, and staff in Shenzhen CDC for their assistance in sample collection.

\section{Authors' affiliations}

T Green, J Dow, Syngenta Central Toxicology Laboratory, UK C N Ong, V Ng, H Y Ong, Dept of Community, Occupational and Family Medicine, National University of Singapore

Z X Zhuang, Center for Disease Control, Shenzhen, China

X F Yang, Center for Disease Control, Guangzhou, China

L Bloemen, Dow Europe SA, Netherlands

\section{REFERENCES}

1 IARC. IARC monographs on the evaluation of carcinogenic risks to humans. Volume 63. Dry cleaning, some chlorinated solvents and other industrial chemicals. Lyon: IARC, 1995.

2 Goeptar AR, Commandeur JNM, van Ommen B, et al. Metabolism and kinetics of trichloroethylene in relation to carcinogenicity. Relevance of the mercapturic acid pathway. Chem Res Toxicol 1995;8:3-21.

3 Henschler D, Vamvakas S, Lammert M, et al. Increased incidence of renal cell tumours in a cohort of cardboard workers exposed to trichloroethylene. Arch Toxicol 1995;70:130-3.
4 Vamvakas S, Bruning T, Thomasson B, et al. Renal cell cancer correlated with occupational exposure to trichloroethylene. J Cancer Res Clin Oncol 1998; 124:374-82.

5 Bruning T, Bolt HM. Renal toxicity and carcinogenicity of trichloroethylene: key results, mechanisms, and controversies. Crit Rev Toxicol 2000;30:253-85.

6 Bruning T, Golka K, Makropoulos V, et al. Preexistence of chronic tubular damage in cases of renal cell cancer after long and high exposure to trichloroethylene. Arch Toxicol 1996;70:259-60.

7 Bruning T, Lammert $M$, Kempes $M$, et al. Influence of polymorphisms of GSTM 1 and GSTT 1 for risk of renal cell cancer in workers with long-term and high occupational exposure to trichloroethylene. Arch Toxicol 1997;71:596-9.

8 Bruning T, Mann H, Metzler $\mathrm{H}$, et al. Subclinical changes in urinary protein excretion of renal cell cancer patients: effect of high occupational exposure to trichloroethylene. Cent Eur J Occup Environ Med 1997;3:167-74.

9 Bruning T, Vamvakas S, Makropoulos V, et al. Acute intoxication with trichloroethylene: clinical symptoms, toxicokinetics, metabolism and development of biochemical parameters for renal damage. Toxicol Sci 1998;41:157-65.

10 Bruning T, Sundberg AGM, Birner G, et al. Glutathione S-transferase $\alpha$ as a marker for tubular damage after trichloroethylene exposure. Arch Toxicol 1999;73:246-54

11 Waller KV, Ward KM, Mahan JD, et al. Current concepts in proteinuria. Clin Chem 1989;35:755-65

12 Berg KJ, Kristoffersen DT, Dioseland O, et al. Reference range of some enzymes and proteins in untimed urine and their stability after freezing. Clin Chim Acta 1998;272:225-30.

13 Green T, Dow J, Foster JR, et al. Formic acid excretion in rats exposed to trichloroethylene: a possible explanation for renal toxicity in long-term studies. Toxicology 1998; 127:39-47.

14 Dow J, Green T. Trichloroethylene induced vitamin B12 and folate deficiency leads to increased formic acid excretion in the rat. Toxicology 2000;146:123-36

15 Chia KS, Mutti A, Tan C, et al. Urinary N-acetyl- $\beta$-D-glucosaminidase activity in workers exposed to inorganic lead. Occup Environ Med 1994;51:125-9.

16 Bernaver U, Birner G, Dekant W, et al. Biotransformation of trichloroethene: dose dependant excretion of 2,2,2-trichloro-metabolites and mercapturic acids in rats and humans after inhalation. Arch Toxicol 1996;70:338-46.

17 SAS. SAS/STAT user's guide, release 6.03 edition. NC: SAS Institute Inc, 1988.

18 DFG-BAT. List of MAK and BAT values. Deutsche Forschungsgemeinschaft, Report No. 29. Germany, Weinhem: VCH Publishers, 1993.

19 Ring E, Zobel G, Erwa W, et al. Urinary excretion of N-acetyl-beta-Dglucosaminidase in proteinuric states. Child Nephrol Urol 1992;12:15-18.

20 Bosomworth MP, Aparicio SR, Hay AW. Urine N-acetyl-beta-Dglucosaminidase-a marker of tubular damage? Nephrol Dial Transplant 1999; 14:620-6.

21 Norman EJ, Martelo OJ, Denton MD. Cobalamin (vitamin B12) deficiency detection by urinary methylmalonic acid quantitation. Blood 1982;59:1128-31.

22 Boeniger MF. Formate in urine as a biological indicator of formaldehyde exposure: a review. Am Ind Hyg Assoc 1987;48:900-8. 